\title{
ANALISIS PENERAPAN WILAYAH KERJA PPAT BERDASARKAN PERATURAN PEMERINTAH NOMOR 24 TAHUN 2016 TENTANG PERUBAHAN ATAS PERATURAN PEMERINTAH NOMOR 37 TAHUN 1998 DI PROVINSI DKI JAKARTA
}

\author{
Ivandi Setiawan \\ (Mahasiswa Program S1 Fakultas Hukum Universitas Tarumanagara) \\ (E-mail: ivandis.fh@stu.untar.ac.id) \\ Rasji \\ (Corresponding Author) \\ (Dosen Hukum Tata Negara Fakultas Hukum Universitas Tarumanagara, Meraih Sarjana Hukum dari \\ Fakultas Hukum Universitas Tarumanagara, Magister Hukum dari Fakultas Hukum Universitas \\ Indonesia) \\ (E-mail: rasji@fh.untar.ac.id)
}

\begin{abstract}
PPAT is a public official authorized to make authentic deeds concerning certain legal acts concerning the right to land or the Property Right of the Flats Unit. Government Regulation No. 24 of 2016 is the latest regulation made by the government to regulate provisions on PPAT. in Government Regulation No. 24 of 2016 in Article 12 paragraph one explained that the scope of work area of PPAT is expanded into one province where in the previous regulation that is government regulation number 37 year 1998 explained that the scope of work of PPAT is only limited to district only. but the fact is now the government regulation number 24 of 2016 has not been applied efficiently, especially in terms of the scope of work of PPAT, it happens because of several factors that hamper causing the loss of effectiveness in Article 12 Paragraph one of Government Regulation No. 24 of 2016 . it is of course also contrary to the legal certainty that the public should have legal certainty with the enactment of the government regulation number 24 of 2016 by the government then the regulation should be applicable in the scope of the working area of PPAT should be applicable in practice in the community. contrary to lex posterior derogate legi priori principle which explains that in the same rules the new rules can replace the old rules. the approach used in this study using the approach of law.
\end{abstract}

Keywords : PPAT, Government Regulation No. 24 of 2016 


\section{PENDAHULUAN}

\section{A. Latar Belakang}

Negara Indonesia berdasarkan Pancasila dan Undang-Undang Dasar Negara Republik Indonesia 1945 (selanjutnya disebut dengan UUD 1945) merupakan Negara hukum. Prinsip dari Negara hukum adalah menjamin kepastian, ketertiban dan perlindungan hukum yang berintikan kebenaran dan keadilan. ${ }^{1}$ Masyarakat sebagai makhluk sosial senantiasa dalam kehidupan sehari-hari akan saling melakukan interaksi sosial dengan masyarakat lainnya. Hubungan-hubungan yang terjadi dalam interaksi sosial tersebut tidak jarang merupakan suatu hubungan hukum, yang tentunya akan melahirkan suatu perbuatan hukum, dan peristiwa hukum yang mempunyai akibat-akibat hukum tertentu. Dalam konteks inilah, kepastian hukum menjadi dasar dalam pranata sistem hukum suatu negara.

Hubungan hukum (rechtsbetrekkingen) adalah hubungan antara dua subyek hukum atau lebih mengenai hak dan kewajiban di satu pihak berhadapan dengan hak dan kewajiban dipihak yang lain. ${ }^{2}$ Hukum mengatur hubungan antara orang yang satu dengan orang yang lain, antara orang dengan masyarakat, antara masyarakat yang satu dengan masyarakat yang lain. Jadi hubungan hukum terdiri atas ikatan-ikatan antara individu dengan individu dan antara individu dengan masyarakat. Hubungan hukum dapat terjadi diantara sesama subyek hukum dan antara subyek hukum dengan barang.

Dalam pergaulan hidup sehari-hari manusia selalu melakukan perbuatanperbuatan untuk memenuhi kepentingannya. Tidak semua perbuatan yang dilakukan oleh setiap manusia merupakan suatu perbuatan hukum. Sebagaiman pengertian perbuatan hukum yaitu segala perbuatan subyek hukum (orang atau badan hukum) yang secara sengaja dilakukan sehingga menimbulkan hak-hak dan kewajiban-

\footnotetext{
${ }^{1}$ SjaifurrachmanHabib Adjie, Aspek Pertanggungjawaban Notaris dalam Pembuatan Akta, (Jakarta: Mandar Maju,2011), hal. 5.

${ }^{2}$ Van Apeldroon, Pengantar Ilmu Hukum, (Jakarta: Pranya Paramita, 2001), hal. 20.
} 
kewajiban. ${ }^{3}$ Perbuatan yang dimaksud, misalnya membuat surat wasiat, membuat perjanjian, dan lain-lain. Maka hanya perbuatan seseorang atau badan hukum yang menimbulkan hak dan kewajiban sajalah yang dapat dikatakan sebagai perbuatan hukum.

Peristiwa hukum (rechtsfeit) adalah peristiwa kemasyarakatan yang akibatnya diatur oleh hukum, Interaksi antara anggota-anggota masyarakat tersebut berbentuk hubungan satu dengan yang lainnya dalam berbagai hal dan dalam berbagai bidang, yang menimbulkan berbagai peristiwa kemasyarakatan. ${ }^{4}$

Menurut pengertian Undang Undang No. 2 Tahun 2014 tentang Jabatan Notaris dalam Pasal satu dijelaskan pengertian notaris, yakni: "Notaris yaitu pejabat umum yang berwenang untuk membuat akta otentik serta kewenangan yang lain seperti maksud dalam undang-undang ini." ${ }^{5}$ lalu jenjang pendidikan notaris juga dapat dilanjutkan ke jenjang selanjutnya yaitu pendidikan Pejabat Pembuat Akta Tanah (selanjutnya disebut dengan PPAT).

Syarat untuk lanjut menjadi PPAT diatur dalam Peraturan Pemerintah No. 24 Tahun 2016 tentang Peraturan Pejabat Pembuat Akta Tanah (selanjutnya disebut dengan PP 24/2016) yang mana disebutkan, syarat untuk menjadi PPAT adalah:

a. Warga Negara Indonesia

b. Berusia paling rendah 22 (dua puluh dua) tahun

c. Berkelakuan baik yang dinyatakan dengan surat keterangan yang dibuat oleh instansi kepolisian setempat

d. Tidak pemah dijatuhi pidana penjara berdasarkan putusan pengadilan yang telah memperoleh kekuatan hukum tetap karena melakukan tindak pidana yang diancam dengan pidana penjara 5 (lima) tahun atau lebih.

e. Sehat jasmani rohanis

f. Berijazah sarjana hukum dan lulusan jenjang strata dua kenotariatan atau lulusan program pendidikan khusus PPAT yang diselenggarakan oleh kementerian yang menyelenggarakan urusan pemerintahan agraria/pertanahan

\footnotetext{
${ }^{3}$ Hasanudin AF, Pengantar Ilmu Hukum, (Jakarta: Pustaka Al Husna Baru, 2004), hal. 83.

${ }^{4}$ Dudu Duswara Machmudin, Pengantar Ilmu Hukum, (Bandung: Refika Aditama, 2010), hal. 40.

${ }^{5}$ Indonesia. Undang-undang Nomor 2 Tahun 2014 tentang Jabatan Notaris (LembaranNegara Republik Indonesia Tahun 2004 Nomor 117, Tambahan Lembaran Negara Republik Indonesia Nomor 4432, Tambahan Lembaran Negara Republik Indonesia Nomor 5491), Pasal 1.
} 
g. Lulus ujian yang diselenggarakan oleh kementerian yang menyelenggarakan urusan pemerintahan di bidang agraria/pertanahan

h. Telah menjalani magang atau nyata-nyata telah bekeda sebagai karyawan pada kantor PPAT paling sedikit 1 (satu tahun) setelah lulus pendidikan kenotariatan. ${ }^{6)}$

PP 24/2016 tentang Perubahan atas Peraturan Pemerintah Nomor 37 Tahun 1998 tentang Peraturan Pejabat Pembuat Akta Tanah (selanjutnya disebut sebagai PP 37/1998) yang disahkan pada tanggal 22 juni 2016 lalu dan telah berlaku sejak saat diundangkan yaitu pada tanggal 27 juni 2016 lalu. Dalam berita tersebut dijelaskan bahwa terdapat beberapa perubahan peraturan yang harus ditaati oleh para pejabat pembuat akta tanah dalam menjalankan tugas jabatannya.

Terkait perubahan wilayah kerja menjadi 1 propinsi ini sudah menjadi perdebatan diantara profesi PPAT sejak tahun 2015 lalu dan pada akhir juni 2016 baru resmi diundangkan dalam bentuk PP 24/2016 tersebut. Maka perubahan wilayah jabatan PPAT dari semula 1 kantor pertanahan Kabupaten/Kota menjadi 1 Propinsi sudah sesuai dengan "nafas" dari UU Jabatan Notaris. Karena dalam praktik PPAT juga dijabat oleh Notaris. Selama ini dalam praktik sering menjadi masalah ketika wilayah jabatan PPAT berada di tempat yang berbeda dengan wilayah kerja Notarisnya. Jika dilihat dari tanggal ditanda-tanganinya PP 24/2016, dan tanggal di undangkannya peraturan pemerintah tersebut pada tanggal 26 Juni 2016, seharusnya PPAT sudah mulai bisa membuat akta-akta untuk tanah-tanah di dalam 1 Propinsi.

Kenyataannya PP 24/2016 tersebut tidak berlaku secara efektif terutama dalam hal tentang ruang lingkup wilayah kerja PPAT. Buktinya yang seharusnya wilayah kerja PPAT bisa propinsi akan tetapi sampai saat ini peraturan tersebut tidak bisa digunakan. Jadi sekarang masih tetap mengacu ke peraturan yang lama yaitu PP 37/1998 yang menjelaskan bahwa ruang lingkup PPAT hanya sebatas kabupaten/kotamadya saja. Dikarenakan sistem pendaftaran online nya belum bisa diinput, hal tersebut dikarenakan dari sistem pusatnya memang belum ada

\footnotetext{
${ }^{6}$ Indonesia, Peraturan Pemerintah Nomor 24 Tahun 2016 tentang peraturan Pejabat Pembuat Akta Tanah (Lembaran Negara Republik Indonesia Tahun 1998 Nomor 52, Tambahan Lembaran N
} 
penjelasannya. Mungkin karena memang PP 24/2016 tersebut memang sulit untuk dterapkan dikarenakan memang ada beberapa faktor-faktor yang dapat menghambatnya yaitu karena badan pertanahan nasional untuk menjadi satu itu sangat mustahil karena untuk periode zaman sekarang, karena jika seandainya badan pertanahan nasional menjadi satu itu sulit dan sistem onlinenya susah.

Peraturan pemerintah tersebut seharusnya bisa diterapkan dan digunakan oleh PPAT dikarenakan adanya asas Lex Posterior Derogat Legi Priori yaitu pada peraturan yang sederajat, peraturan yang paling baru melumpuhkan peraturan yang lama. Jadi peraturan yang telah diganti dengan peraturan yang baru, secara otomatis dengan asas ini peraturan yang lama tidak berlaku lagi. ${ }^{7)}$ Akan tetapi pada kenyataannya asas tersebut seperti tidak efisien terhadap PP 24/2016.

Contoh kasus nya adalah seperti yang pernah telah wawancarai, wawancara nya dilakukan disalah satu kantor notaris di daerah Jakarta Barat. Memang pada saat itu ingin dicoba untuk input data peralihan hak-jual beli tanah yang tanahnya tersebut berada didaerah kabupaten Jakarta Utara. Seharusnya sesuai dengan pasal 12 ayat satu PP 24/2016 wilayah kerja nya PPAT tersebut harusnya menjadi satu provinsi akan tetapi buktinya hal tersebut tidak bisa diterapkan dan hasilnya tetap memakai peraturan yang lama yang wilayah kerjanya sebatas kabupaten saja.

Berdasarkan uraian diatas diangkatlah judul penelitian ini adalah: "Analisis Penerapan Wilayah Kerja PPAT Berdasarkan Peraturan Pemerintah Nomor 24 Tahun 2016 tentang Perubahan Atas Peraturan Pemerintah Nomor 37 Tahun 1998 Di Provinsi DKI Jakarta”.

\section{B. Permasalahan}

Berdasarkan uraian latar belakang di atas, maka permasalahan yang hendak dirumuskan adalah mengapa meski sudah ada Peraturan Pemerintah Nomor 24 Tahun 2016 tersebut, tetapi pada kenyataannya wilayah kerjanya PPAT tersebut masih pada ruang lingkup kabupaten ?

\footnotetext{
${ }^{7}$ Zaeni Asyhadie, Pengantar Ilmu Hukum, (Jakarta: PT RajaGrafindo Persada, 2014), hal. 66.
} 


\section{Metode Penelitian}

Metode penelitian hukum merupakan suatu proses untuk menemukan aturan hukum, prinsip-prinsip hukum, maupun doktrin-doktrin hukum guna menjawab isu hukum yang akan dihadapi.

\section{Jenis Penelitian}

Berdasarkan permasalahan yang diteliti, maka jenis penelitian yang digunakan adalah penelitian hukum normatif. Penelitian hukum normatif atau metode penelitian hukum kepustakaan adalah metode atau cara yang dipergunakan di dalam penelitian hukum yang dilakukan dengan cara meneliti bahan pustaka yang ada. Berdasarkan pemahaman diatas maka penelitian ini akan meneliti hukum yang tertulis yaitu PP 24/2016.

\section{Jenis dan Sumber Data}

Metode Penelitian normative terdapat 3 (tiga) macam bahan pustaka yang dapat digunakan, yakin:

a. Bahan Hukum Primer

Bahan hukum primer merupakan bahan hukum yang besifat autoritatif, artinya mempunyai otoritas ${ }^{8)}$ bahan hukum primer yang digunakan terdiri dari PP 24/2016 dan PP 37/1998.

\section{b. Bahan Hukum Sekunder}

Bahan hukum sekunder berupa semua publikasi tentang hukum yang bukan merupakan dokumen-dokumen resmi. Bahan hukum sekunder yang digunakan dalam penulisan ini adalah berbagai kepusakaan hukum yakni buku atau jurnal hukum yang berisi mengenai prinsip-prinsip dasar (asas hukum), pandangan para ahli hukum (doktrin) berupa semua publikasi tentang hukum.

c. Bahan Non-Hukum

Bahan penulisan yang terdiri atas buku teks bukan hukum yang terkait dengan penelitian, ${ }^{9)}$ seperti Kamus Besar Bahasa Indonesia dan hasil wawancara.

\footnotetext{
${ }^{8)}$ Peter Mahmud Marzuki, Penelitian Hukum, Edisi Revisi (Jakarta: Kencana Prenada Media Group, 2011). hal. 93
} 


\section{Teknik Pengumpulan Data}

Dalam penelitian hukum ini, teknik pengumpulan data yang digunakan adalah dengan melakukan studi pustaka (library research) terhadap bahan-bahan hukum, baik bahan hukum primer, bahan hukum sekunder maupun bahan hukum tersier. Penelusuran bahan-bahan hukum tersebut dilakukan dengan membaca, melihat, mendengarkan, penelusuran melalui internet, maupun mengadakan wawancara dengan pihak terkait.

\section{Teknik Pengolahan Data}

Pengolahan data dilakukan dengan cara melakukan seleksi data sekunder atau bahan hukum, kemudian melakukan klasifikasi menurut penggolongan bahan hukum dan menyusun data hasil penelitian tersebut secara sistematis, tentu saja hal tersebut dilakukan secara logis, artinya ada hubungan dan keterkaitan bahan hukum satu dengan bahan hukum lainnya untuk mendapatkan gambaran umum dari hasil penelitian.

\section{Tenik Analisa Data}

Analisis data merupakan kegiatan dalam penelitian yang berupaya melakukan kajian atau telaah terhadap hasil pengolahan data yang dibantu dengan teori yang telah didapatkan sebelumnya. Metode analisis yang dipergunakan dalam penelitian ini adalah metode analisis kualitatif. Metode analisis kualitatif dipergunakan untuk menganalisis dan mengeksplanasi hasil penelitian, dan kemudian menyajikan secara kualitatif. Penelitian yang dilakukan lebih ditujukan kepada pendekatan undangundang.

\section{PEMBAHASAN}

\section{A. Hasil Penelitian}

1. Kasus Posisi

Seperti yang kita ketahui PPAT adalah pejabat umum yang diberi kewenangan untuk membuat akta-akta otentik mengenai perbuatan hukum

\footnotetext{
${ }^{9)}$ Mukti Fajar ND dan Yulianto Achmad, Op. Cit., hal. 43.
} 
tertentu mengenai hak atas tanah atau Hak Milik Satuan Rumah Susun. Perbuatan hukum nya seperti akta mengenai peralihan hak dan akta mengenai pembebanan hak berupa hibah, jual beli, tukar menukar, serta pembagian hak bersama. Semua kewenangan PPAT tersebut dapat diterapkan didalam ruang lingkup kerja PPAT nya masing-masing.

Tetapi bagaimana jika semua kewenangan PPAT tersebut tidak dapat diterapkan sebagaimana mestinya didalam ruang lingkup kerja PPAT itu sendiri dikarenakan peraturan tentang PPAT tersebut masih menggunakan peraturan nya yang lama, tentu saja akibat dari hal tersebut akan menimbulkan berbagai dampak dan akibat hukum yang terjadi di dalam lingkungan masyarakat.

Kronologi kasus ini bermula pada saat itu penulis sedang menemani keluarganya sendiri yang ingin memproses jual beli tanah milik keluarganya sendiri, saat itu penulis mengetahui kalau Peraturan Pemerintah Nomor 37 Tahun 1998 tentang PPAT tersebut telah di gantikan oleh Peraturan Pemerintah Nomor 24 Tahun 2016 tentang PPAT. Pada Peraturan Pemerintah Nomor 24 Tahun 2016 tentang PPAT tersebut di jelaskan pada pasal 12 Ayat satu nya bahwa ruang lingkup kerja PPAT telah diperluas menjadi satu Provinsi, berdasarkan peraturan pemerintah sebelumnya yaitu menurut Peraturan Pemerintah Nomor 37 Tahun 1998 tentang PPAT bahwa ruang lingkup kerja PPAT tersebut hanya sebatas Kabupaten atau Kotamadya saja.

Berdasarkan Peraturan Pemerintah Nomor 37 Tahun 1998 tentang PPAT tersebut bahwa jika kita ingin melakukan Pendaftaran Tanah, Hibah, Jual Beli Tanah yang ada di Jakarta Barat tersebut bisa dilakukan melalui PPAT yang ada pada wilayah kabupatennya yaitu wilayah Jakarta Barat itu sendiri. Tetapi jika kita lihat pada peraturan yang barunya yaitu Peraturan Pemerintah Nomor 24 Tahun 2016 tentang PPAT tersebut bahwa jika kita ingin melakukan Pendaftaran Tanah, Hibah, Jual Beli Tanah serta Hak Tanggungan yang ada pada daerah Jakarta Barat dapat dilakukan di Kantor PPAT yang berada di luar Jakarta Barat 
seperti pada daerah Jakarta Utara serta Jakarta Selatan dan lain-lainnya selama daerah tersebut masih dalam ruang lingkup Satu Provinsi.

Berdasarkan Peraturan Pemerintah Nomor 24 Tahun 2016 tentang PPAT tersebut seharusnya kita bisa melakukan Jual Beli Tanah di Jakarta Barat di Kantor PPAT di Jakarta Utara akan tetapi pada prakteknya tidak berlaku demikian, harusnya berdasarkan Teori bahwa Jual Beli tersebut dapat dilakukan di Kantor PPAT di Jakarta Utara tetapi tidak dapat diterapkan sebagaimana mestinya dalam prakteknya. Hal ini disebabkan karena pada sistem online yang ada pada Kantor PPAT tersebut yang dimana pada sistem online tersebut masih menggunakan Peraturan Pemerintah Nomor 37 Tahun 1998 yang dimana ruang lingkup PPAT masih hanya sebatas kabupaten saja, jadi sistem online nya tidak bisa menerima proses Jual Beli Tanah tersebut yang bukan berada dalam ruang lingkup kabupaten tersebut.

Setelah penulis mengetahui hal tersebut maka penulis mencoba mencari Kantor PPAT yang ada di dalam ruang lingkup Jakarta Barat yaitu salah satunya Kantor PPAT yang ada didaerah Grogol Pertamburan, setelah bertemu PPAT di daerah Jakarta Barat tersebut dan ternyata proses jual beli tanah tersebut dapat terselesaikan juga.

Permasalahan yang ditanyakan adalah kenapa Peraturan Pemerintah yang lama yang berlaku yaitu Peraturan Pemerintah Nomor 37 Tahun 1998 tentang PPAT tersebut, seharusnya Peratutan Pemerintah Nomor 24 Tahun 2016 tentang PPAT tersebut yang berlaku karena Peraturan Pemerintah Nomor 24 Tahun 2016 tentang PPAT tersebut berkedudukan lebih tinggi dan telah menggantikan Peraturan Pemerintah Nomor 37 Tahun 1998 tentang PPAT sejak bulan Juli 2016 yang pada saat itu Presiden Republik Indonesia yaitu Bapak Joko Widodo yang telah mencabut Peraturan Pemerintah Nomor 37 Tahun 1998 tentang PPAT tersebut dan digantikan dengan Peraturan Pemerintah Nomor 24 Tahun 2016 tentang PPAT. 
Berdasarkan tahun di sahkan nya Peraturan Pemerintah Nomor 24 Tahun 2016 tentang PPAT tersebut maka seharusnya pada Tahun 2018 sekarang ini Peraturan Pemerintah Nomor 24 Tahun 2016 tersebut dapat di gunakan dan di terapkan di dalam kehidupan masyarakat karena dapat mempermudah masyarakat untuk melakukan proses Jual Beli Tanah, Hibah, Hak Tanggungan dan lain-lainnya.

Tetapi setelah 2 tahun berlalu pada prakteknya bahwa Peraturan Pemerintah Nomor 24 Tahun 2016 tentang PPAT tersebut tidak dapat diterapkan seperti sebagaimana mestinya dan justru masih mengacu pada Peraturan Pemerintah Nomor 37 Tahun 1998 yang telah di cabut oleh Presiden Republik Indonesia yaitu Bapak Joko Widodo. Peraturan Pemerintah tersebut seharusnya sudah dapat digunakan dan diterapkan karena jangka waktu 2 tahun itu sudah termasuk cukup lama dalam penerapan berlakunya Peraturan pemerintah tersebut karena jika dilihat dari asas hukum umum yaitu asas Lex Posterior Derogat Legi Priori bahwa pada peraturan yang sederajat maka peraturan yang baru yang dapat mengesampingkan peraturan yang lama maka seharusnya Peraturan Pemerintah Nomor 24 Tahun 2016 tentang PPAT tersebut sah untuk di terapkan. Akibat dari tidak diterapkan sebagaimana mestinya Peraturan Pemerintah Nomor 24 tahun 2016 tentang PPAT tersebut ketidakpastian hukum pun terjadi di lingkungan masyarakat karena masyarakat menjadi bingung kenapa peraturan pemerintah yang baru tidak dapat digunakan seperti yang seharusnya.

\section{Substansi}

Untuk melengkapi data hasil penelitian maka dilakukan wawancara untuk menambah bahan referensi untuk memperkuat argumentasi pada analisis melalui wawancara dengan narasumber.

1. Dr. Hasni, S.H, M.H.

a. Apakah asas lex posterior derogate legi priori bisa dikaitkan dengan kasus yang sedang dipermasalahkan? 
Iya, asas tersebut memang dapat dikaitkan dengan kasus yang sedang diangkat yaitu tentang permasalahan ruang lingkup wilayah kerja PPAT tersebut karena pada asas lex posterior derogate legi priori tersebut dijelaskan bahwa pada peraturan yang sederajat yaitu Peraturan Pemerintah Nomor 24 Tahun 2016 dan Peraturan Pemerintah Nomor 37 Tahun 1998 tersebut maka peraturan yang paling baru lah dapat menggantikan posisi peraturan yang lama yang dimana jadi Peraturan Pemerintah Nomor 24 Tahun 2016 tersebut dapat lah diterapkan akan tetapi memang pada kenyataannya saat ini bahwa Peraturan Pemerintah Nomor 24 tahun 2016 tersebut tidak dapat diterapkan seperti seharusnya maka dari itu asas lex posterior derogate legi priori tersebut terpaksa dikesampingkan karena memang Peraturan Pemerintah Nomor 24 Tahun 2016 tersebut tidak dapat dijalankan.

b. Mengapa Peraturan Pemerintah Nomor 24 Tahun 2016 tersebut dibuat kalau ternyata hasilnya justru tidak dapat diterapkan?

Karena mungkin saja pada saat masa penyusunan Peraturan Pemerintah Nomor 24 Tahun 2016 tersebut terlalu terburu-buru dan kurangnya diskusi antara para PPAT dan mungkin juga pada saat pembuatannya itu tidak hadirnya IPPAT dan ASPAT serta bisa jadi juga karena faktor beberapa pihak yang membuat peraturan tersebut semaunya saja tanpa diskusi dan persetujuan orang lainnya.

c. Apakah ada dampak dari tidak efisiennya Peraturan Pemerintah Nomor 24 Tahun 2016 ini terhadap lingkup masyarakat umum?

Dampak nya tentu saja ada terhadap masyarakat umum tersebut karena ada beberapa masyarakat yang pastinya tentu merasa kalau mereka tidak mendapatkan kejelasan dan kepastian hukum yang jelas karena Peraturan Pemerintah Nomor 24 Tahun 2016 tersebut telah disetujui oleh presiden kita tapi ternyata malah tidak dapat diterapkan dengan baik. Karena jika Peraturan Pemerintah Nomor 24 Tahun 2016 tersebut dapat diterapkan 
dengan seperti yang seharusnya maka masyarakat umum yang ada didaerah Jakarta Barat jika ingin melakukan pendaftaran tanah yang ada didaerah Jakarta Selatan maka masyarakat yang di Jakarta Barat tersebut tidak perlu repot-repot lagi pergi ke PPAT di Jakarta Selatan untuk melakukan pendaftaran tanah karena dengan pergi ke PPAT yang ada di daerah Jakarta Barat pun sudah bisa dilakukan pengurusan akan tetapi realismenya begitu bahwa Peraturan Pemerintah Nomor 24 Tahun 2016 tersebut efektivitasnya tidak ada.

d. Apakah ada dampak terhadap para PPAT dengan tidak berlakunya Peraturan Pemerintah Nomor 24 Tahun 2016 tersebut?

Tentu saja ada dampaknya baik itu yang positif maupun ada yang negatifnya karena jika di lihat dari sisi positifnya tersebut maka dengan adanya Peraturan Pemerintah Nomor 24 Tahun 2016 tersebut maka PPAT dapat memperluas ruang lingkup wilayah kerjanya sehingga dapat meningkatkan Customernya yang dimana pelanggannya dapat bertambah karena dari luar kabupatennya dapat diurus di kantor PPAT tersebut. Dan ada juga dari sisi negatifnya yang dimana dengan adanya Peraturan Pemerintah Nomor 24 Tahun 2016 tersebut maka akan terjadi perebutan Customer yang dimana pelanggan yang biasanya di kantor notaris tersebut menjadi pindah karena mungkin saja ada notaris yang berada lebih dekat dengan tempat tinggalnya.

e. Apakah masyarakat umum dapat melakukan seperti aksi protes terkait dengan Peraturan Pemerintah Nomor 24 Tahun 2016 tersebut?

Bisa, masyarakat umum tentu saja dapat melakukan aksi protes atau keberatan terkait Peraturan Pemerintah Nomor 24 Tahun 2016 tersebut dengan cara dapat mencoba mengajukan keberatan kepada Badan Pertanahan Nasional serta kepada Menteri Hukum dan HAM.

2. Notaris Makmur Tridharma, S.H. 
a. Apabila ada seorang klien yang memiliki tanah yang terletak di daerah Jakarta Utara tetapi ia ingin menggunakan jasa PPAT yang ada di daerah Jakarta Barat, apakah hal tersebut bisa di lakukan?

Bisa, hal tersebut seharusnya bisa dilakukan karena Peraturan Pemerintah Nomor 24 Tahun 2016 tersebut telah disahkan sejak 2 tahun yang lalu yang dimana pada Pasal 12 Peraturan Pemerintah Nomor 24 Tahun 2016 tersebut di jelaskan kalau ruang lingkup kerja PPAT tersebut diperluas menjadi satu provinsi sehingga jangankan antara Jakarta Utara dan Jakarta Barat saja bahkan bisa melebihi daerah tersebut, Bahkan bisa antara daerah Tangerang dan daerah Jakarta Barat selama daerah tersebut masih dalam ruang lingkup provinsi. Akan tetapi itu hanya secara teori nya saja karena fakta nya sekarang ini tidak bisa memakai Peraturan Pemerintah Nomor 24 Tahun 2016 karena pada saat kita ingin melakukan input data melalui sistem online nya ternyata tidak bisa jadi mau tidak mau tetap memakai Peraturan Pemerintah Nomor 37 Tahun 1998 yang daerah ruang lingkup kerja PPAT nya sebatas kabupaten saja.

b. Apakah Pasal 12 Ayat satu Peraturan Pemerintah Nomor 24 Tahun 2016 tersebut hanya berlaku di daerah DKI Jakarta saja?

Tentu saja tidak, Peraturan Pemerintah Nomor 24 Tahun 2016 Tersebut dapat berlaku di seluruh daerah yang ada di Negara Indonesia baik itu di daerah yang terpencil sekalipun karena Peraturan Pemerintah Nomor 24 Tahun 2016 tersebut diterangkan memang untuk berlaku diseluruh wilayah yang ada di Negara Indonesia.

c. Apakah terdapat sanksi bagi PPAT jika tidak melaksanakan Peraturan Pemerintah Nomor 24 Tahun 2016 tersebut?

Tentu saja tidak ada sanksi bagi PPAT yang tidak menjalankan peraturan tersebut, tetapi permasalahannya sekarang ini bukanlah PPAT yang tidak mau menjalankan hal tersebut tetapi karena memang peraturan tersebut belum bisa diterapkan dalam prakteknya jadi kesalahan tersebut tidak berada 
pada PPAT nya karena kami para PPAT telah mencoba untuk menerapkan yang ada pada pasal 12 Ayat satu Peraturan Pemerintah Nomor 24 Tahun 2016 tersebut tetapi memang ternyata belum bisa diterapkan.

d. Apakah sistem online BPN merupakan produk peraturan atau kebijakan?

Jelas sekali kalau itu merupakan kebijakan karena kalau dalam bentuk tertulis maka itu baru produk peraturan.

e. Apakah dengan menolak permohonan dari klien tersebut maka PPAT dapat di kenakan sanksi?

Tentu saja tidak ada sanksi, karena memang belum ada peraturan nya sampai sekarang ini yang isinya membahas untuk memberikan sanksi kepada PPAT kalau PPAT tersebut menolak permohonan klien.

f. Apakah terdapat sanksi bagi Pejabat Kantor Pertanahan yang menolak permohonan klien tersebut andai kata PPAT terkait menerima permintaan klien?

Tentu saja tidak ada sanksinya karena Sampai saat ini belum ada peraturan yang memberikan sanksi terhadap penolakan oleh pejabat kantor pertanahan terhadap pengajuan permohonan klien, tetapi ada perbedaan nya jika hal tersebut terjadi dengan PPAT dimana jika penolakan tersebut dilakukan secara formal atau tertulis maka dapat diajukan gugatan melalui PTUN tersebut kepada PPAT itu.

\section{Notaris Aris Hendrawan Halim S.H}

a. Apabila ada seorang klien yang memiliki tanah yang terletak di daerah Jakarta Utara tetapi ia ingin menggunakan jasa PPAT yang ada di daerah Jakarta Barat, apakah hal tersebut bisa di lakukan?

Hal tersebut bisa dilakukan, karena jika mengacu berdasarkan Pasal 12 Ayat satu Peraturan Pemerintah Nomor 24 Tahun 2016 tentang PPAT tersebut dijelaskan bahwa seorang PPAT memiliki wilayah kerja yakni satu provinsi, maka jasa atas pengurusan tanah yang terletak di Jakarta Utara yang di lakukan oleh PPAT dengan wilayah kerja di Jakarta Barat dapat di 
laksanakan. Tetapi hal ini belum dapat dilakukan dikarenakan terdapat masalah administrasi pada sistem di kantor pertanahan itu sendiri.

b. Apakah Pasal 12 Ayat satu Peraturan Pemerintah Nomor 24 Tahun 2016 tersebut hanya berlaku di daerah DKI Jakarta saja?

Jadi begini Peraturan Pemerintah Nomor 24 Tahun 2016 tentang PPAT itu merupakan suatu Peraturan Pemerintah, Peraturan Pemerintah itu merupakan suatu delegasi dari undang-undang sehingga berdasarkan Pasal 5 Ayat dua Undang-undang Dasar Negara Republik Indonesia 1945 maka Peraturan Pemerintah tersebut berlaku nasional.

c. Apakah terdapat sanksi bagi PPAT jika tidak melaksanakan Pasal 12 Ayat satu Peraturan Pemerintah Nomor 24 Tahun 2016 tersebut?

Tentu saja tidak ada sanksi, karena berdasarkan Peraturan Pemerintah Nomor 24 Tahun 2016 pasal 12 Ayat satu nya itu hanya bersifat mengatur saja, hal tersebut bukan merupakan ketentuan yang bersifat memaksa sehingga maka tidak diharuskan disertai sanksi.

d. Apakah sistem online BPN merupakan produk peraturan atau kebijakan?

Sistem Online BPN itu bukan merupakan produk peraturan, karena produk peraturan itu merupakan ketentuan berbentuk tulisan sedangkan sampai saat ini juga menteri saja belum menetapkan peraturan apapun. Sehingga sistem online BPN ini adalah merupakan produk kebijakan dari menteri sebagai pejabat pemerintahan.

e. Apakah ada dampak terhadap para PPAT dengan tidak berlakunya Peraturan Pemerintah Nomor 24 Tahun 2016 tersebut?

Ada, karena dengan tidak berlakunya Peraturan Pemerintah Nomor 24 Tahun 2016 tersebut maka jika ada klien yang berada di daerah Jakarta Barat yang ingin memproses hibah dan pendaftaran tanah dan lain-lainnya yang berada di daerah Bogor maka seharusnya bisa di proses karena wilayah kerja PPAT yang di daerah Jakarta Barat seharusnya sudah bisa memproses yang berada di daerah Bogor akan tetapi karena memang efektivitasnya Peraturan 
Pemerintah Nomor 24 Tahun 2016 tersebut masih dipertanyakan sampai sekarang ini maka klien tersebut harus pergi ke PPAT yang berada di wilayah bogor.

\section{Notaris Rudy Siswanto S.H}

a. Apabila ada seorang klien yang memiliki tanah yang terletak di daerah Jakarta Utara tetapi ia ingin menggunakan jasa PPAT yang ada di daerah Jakarta Barat, apakah hal tersebut bisa di lakukan?

Hal tersebut sebenernya bisa untuk dilakukan saat ini, akan tetapi faktanya sekarang hal tersebut belum bisa dilakukan karena mungkin saja masih terdapat kesulitan-kesulitan dalam menerapkan Pasal 12 Ayat satu Peraturan Pemerintah Nomor 24 Tahun 2016 tersebut. Padahal memang jika kita lihat dari pengesahan Peraturan Pemerintah Nomor 24 Tahun 2016 tersebut seharusnya peraturan tersebut sudah bisa diterapkan dalam prakteknya tetapi karena sulit dan banyak kendala jadi mungkin efektifitas dari Peraturan Pemerintah Nomor 24 Tahun 2016 tersebut belum bisa diterapkan.

b. Apakah Pasal 12 Ayat satu Peraturan Pemerintah Nomor 24 Tahun 2016 tersebut hanya berlaku di daerah DKI Jakarta saja?

Tidak, Peraturan Pemerintah Nomor 24 Tahun 2016 tersebut dapat berlaku secara nasional yang artinya dapat berlaku di seluruh daerah di Indonesia karena di jelaskan di dalam Peraturan Pemerintah Nomor 24 Tahun 2016 tersebut bahwa memang peraturan tersebut berlakunya tidak hanya di wilayah Jakarta saja.

c. Apakah terdapat sanksi bagi PPAT jika tidak melaksanakan Pasal 12 Ayat satu Peraturan Pemerintah Nomor 24 Tahun 2016 tersebut?

Tidak akan ada sanksi nya karena di dalam Peraturan Pemerintah Nomor 24 Tahun 2016 tersebut tidak menjelaskan kalau PPAT tidak menjalankan hal tersebut maka akan dikenakan sanksi, akan tetapi jika Peraturan Pemerintah Nomor 24 Tahun 2016 tersebut efektivitasnya sudah dapat diterapkan maka PPAT harus menerapkan Peraturan Pemerintah Nomor 24 Tahun 2016 
tersebut. Sedangkan untuk saat ini tidak diterapkan tidak akan ada masalah karena memang kesalahan yang terjadi pada penerapan Peraturan Pemerintah Nomor 24 Tahun 2016 tersebut ada lah kesalahan pada pihak yang berwenang yang membuat peraturan tersebut.

d. Apakah asas lex posterior derogate legi priori bisa dikaitkan dengan kasus yang sedang dipermasalahkan?

Tentu saja bisa karena asas lex posterior derogate legi priori itu merupakan asas hukum umum sehingga bisa dikaitkan dengan Peraturan Pemerintah Nomor 24 Tahun 2016 yang sedang dipermasalahkan ini, karena Peraturan Pemerintah Nomor 24 Tahun 2016 ini seharusnya sudah bisa diterapkan didalam lingkungan masyarakat dan menggantikan Peraturan Pemerintah Nomor 37 Tahun 1998.

\section{Notaris Laurensia Siti Nyoman S.H}

a. Apabila ada seorang klien yang memiliki tanah yang terletak di daerah Jakarta Utara tetapi ia ingin menggunakan jasa PPAT yang ada di daerah Jakarta Barat, apakah hal tersebut bisa di lakukan?

Bisa saja, karena ada Peraturan Pemerintah Nomor 24 Tahun 2016 di pasal 12 Ayat satu nya di jelaskan kalau ruang lingkup wilayah kerja PPAT diperluas menjadi satu provinsi sehingga klien yang ada didaerah Jakarta Utara tersebut bisa menggunakan jasa PPAT yang berada di daerah Jakarta Barat. Tetapi memang dalam prakteknya tidak seperti itu, penerapannya Peraturan Pemerintah Nomor 24 Tahun 2016 tersebut masih di pertanyakan karena memang setelah kita coba melakukan penginputan data melalui sistem online yang telah disediakan oleh BPN tersebut ternyata hal tersebut tidak dapat dilakukan, tetap masih mengacu pada Peraturan Pemerintah Nomor 37 Tahun 1998 tersebut sehingga ruang lingkup wilayah kerja PPAT nya masih tetap sebatas kabupaten saja.

b. Apakah asas lex posterior derogate legi priori bisa dikaitkan dengan kasus yang sedang dipermasalahkan? 
Bisa dikaitkan, karena asas itu menjelaskan tentang peraturan yang sederajat yang menggantikan peraturan yang lamanya. Memang kasus yang dipermasalahkan tersebut ada kaitannya karena menggantikan peraturan yang lamanya yaitu Peraturan Pemerintah Nomor 37 Tahun 1998 tetapi memang sampai saat ini kebalikannya justru Peraturan Pemerintah Nomor 24 Tahun 2016 tersebut seperti tidak berlaku dan justru Peraturan Pemerintah Nomor 37 Tahun 1998 yang berlaku sekarang ini.

c. Apakah menurut Ibu bahwa Pasal 12 Ayat satu itu nantinya bisa diterapkan seperti yang seharusnya?

Menurut saya hal tersebut sangat sulit untuk diterapkan saat ini sekarang ataupun nanti kedepannya karena jika ruang lingkup wilayah kerja PPAT nya menjadi satu provinsi maka BPN nya pun otomatis hanya menjadi satu saja sehingga tidak ada lagi yang namanya BPN yang di Jakarta Barat, Utara, Selatan dan lain-lainnya begitu juga dengan BPN lainnya. Dalam hal BPN hanya menjadi satu saja itu sangat sulit karena semua proses urusan tanah di gabungkan menjadi satu dan diselesaikan oleh satu BPN, hal tersebut sangat sulit karena dalam prakteknya saat ini BPN yang di daerah Jakarta Selatan saja masih sering ditemukan beberapa kendala dalam memproses penyelesaian urusan Jual beli tanah dan lain-lainnya sehingga menurut saya Pasal 12 Ayat satu Peraturan Pemerintah Nomor 24 Tahun 2016 tersebut sangat sulit untuk di terapkan.

d. Apabila sulit untuk diterapkan lalu kenapa pemerintah membuat peraturan tersebut?

Mungkin saja terjadi kesalahan dalam pembuatan Peraturan Pemerintah Nomor 24 Tahun 2016 tersebut dan mungkin saja Peraturan Pemerintah Nomor 24 Tahun 2016 tersebut ingin dilakukan uji coba dulu dalam kehidupan prakteknya tetapi ternyata mereka tidak memikirkan apa resikonya jika Peraturan Pemerintah Nomor 24 Tahun 2016 tersebut tidak dapat berlaku seperti yang seharusnya. 


\section{B. Analisis}

\section{Penerapan Wilayah Kerja PPAT Berdasarkan Peraturan Pemerintah} Nomor 24 Tahun 2016 Di Provinsi DKI Jakarta

PPAT merupakan pejabat umum yang berwenang untuk membuat akta tanah baik itu dalam bentuk hibah, jual beli tanah, serta pendaftaran tanah dan lainlainnya. Aktanya tersebut dapat dimaknai sebagai upaya Negara dalam menciptakan kepastian hukum dan perlindungan hukum bagi anggota masyarakat, PPAT itu sendiri mempunyai peraturan-peraturan khusus yang mengatur lebih dalam tentang apa itu PPAT dan mengatur wilayah kerja dari PPAT itu sendiri yang peraturannya tersebut telah dibuat oleh pemerintah dalam bentuk Peraturan Pemerintah Nomor 37 Tahun 1998 tentang PPAT.

Peraturan Pemerintah Nomor 37 Tahun 1998 tersebut dijelaskan pada pasal 12 Ayat satu nya bahwa ruang lingkup wilayah kerja PPAT seluas kotamadya atau kabupaten yang berarti ruang lingkup wilayah kerja PPAT pada saat itu sebatas kabupaten saja yaitu pada daerah Jakarta Barat hanya bisa melakukan proses jual beli dan pendaftaran tanah pada kantor notaris dan PPAT di Jakarta Barat saja. Pada bulan juni tahun 2016 yang lalu telah terjadi perubahan pada Peraturan Pemerintah yang mengatur tentang PPAT tersebut, Peraturan Pemerintah Nomor 37 Tahun 1998 tersebut telah dicabut dan digantikan dengan Peraturan Pemerintah Nomor 24 Tahun 2016 tentang PPAT yang telah disetujui dan di sahkan oleh Presiden Joko Widodo di Jakarta.

a. Tidak efisiennya Peraturan Pemerintah Nomor 24 Tahun 2016 tentang PPAT

Tidak efisiennya Peraturan Pemerintah Nomor 24 Tahun 2016 tentang PPAT terkait pasal 12 Ayat satu yang membahas tentang wilayah kerja PPAT yang wilayah kerja PPAT tersebut telah diperluas menjadi satu provinsi akan tetapi faktanya yang terjadi di lapangan justru tidak berlaku demikian. Sampai saat ini wilayah kerja PPAT tetap hanya sebatas kabupaten atau kotamadya saja padahal Peraturan Pemerintah Nomor 37 Tahun 1998 tersebut telah dicabut 2 tahun yang 
lalu dan telah digantikan dengan Peraturan Pemerintah Nomor 24 Tahun 2016 dan telah di sahkan oleh presiden Joko Widodo.

Berdasarkan asas lex posterior derogate legi priori dijelaskan bahwa pada peraturan yang baru dapat menggantikan peraturan yang lama. Tetapi hal tersebut tidak sesuai dengan teorinya, karena saat ini memang masih memakai Peraturan Pemerintah Nomor 37 Tahun 1998 terutama pada pasal 12 Ayat satu tentang wilayah kerja PPAT tersebut. Peraturan Pemerintah Nomor 24 Tahun 2016 tersebut tidak dapat dijalankan sesuai dengan seharusnya.

Sesuai dengan asas lex posterior derogate legi priori bahwa menurut Dr. Hasni S.H.,M.H, Peraturan Pemerintah Nomor 24 Tahun 2016 tersebut memang tidak dapat dijalankan sampai saat ini sehingga mau tidak mau Peraturan Pemerintah Nomor 24 Tahun 2016 tersebut belum dapat digunakan dan tetap memakai Peraturan Pemerintah Nomor 37 Tahun 1998 tersebut dan memang dengan terjadinya hal tersebut maka ketidakpastian hukum pun juga menjadi dipertanyakan.

Tetapi dalam prakteknya justru sebaliknya yaitu Peraturan Pemerintah Nomor 37 Tahun 1998 yang terikat dan berlaku didalam lingkungan masyarakat tersebut padahal Peraturan Pemerintah Nomor 37 Tahun 1998 tersebut telah dicabut dan di gantikan dengan Peraturan Pemerintah Nomor 24 Tahun 2016 tetapi sebaliknya peraturan yang lama justru yang berlaku dan bersifat mengikat terhadap masyarakat sehingga ruang lingkup wilayah kerja PPAT tersebut hanya sebatas kabupaten saja.

Peraturan Pemerintah Nomor 24 Tahun 2016 tersebut sulit untuk diterapkan secara langsung dalam prakteknya karena dengan diterapkannya Peraturan Pemerintah Nomor 24 Tahun 2016 tersebut maka BPN yang semulanya dibagibagi menjadi beberapa bagian seperti didaerah Jakarta Utara, Barat, Selatan, dan Timur tersebut akan menjadi satu BPN saja karena ruang lingkup wilayahnya telah diperluas menjadi satu provinsi sehingga hal tersebut sangat mustahil untuk sekarang ini diterapkan BPN dengan sistem tersebut. 
Notaris Makmur Tridharma mengatakan bahwa mungkin saja hal tersebut nantinya bisa diterapkan di lingkungan masyarakat akan tetapi sebelum bias diterapkan seharusnya telah dilakukan uji coba dulu didalam lapangan nya langsung apakah perluasan wilayah kerja menjadi satu provinsi tersebut dapat diterapkan secara langsung, bukan nya seperti saat ini dimana Peraturan Pemerintah Nomor 24 Tahun 2016 tersebut pastinya pemerintah belum melakukan uji coba didalam lapangan nya langsung tetapi sudah mengesahkan dan mengeluarkan Peraturan Pemerintah Nomor 24 Tahun 2016 tersebut terkait dengan Pasal 12 Ayat satu tersebut.

b. Akibat karena tidak efisiennya Peraturan Pemerintah Nomor 24 Tahun 2016

Akibat yang terjadi karena tidak efisiennya Peraturan Pemerintah Nomor 24 Tahun 2016 tersebut terjadi pada ruang lingkup masyarakat serta pada PPAT itu sendiri. Akibat tidak efisiennya Peraturan Pemerintah Nomor 24 Tahun 2016 tersebut pada lingkungan masyarakat yaitu dengan hal tersebut masyarakat jadinya tidak mendapatkan kepastian hukum yang seharusnya berdasarkan teori Nilai Dasar hukum yang di jelaskan oleh Gustav bahwa kepastian hukum tersebut termasuk didalam prinsip Negara hukum.

Masyarakat yang seharusnya tinggal didaerah Jakarta Barat dapat melakukan jual beli tanah yang berada di daerah Jakarta Utara dengan datang ke kantor notaris dan PPAT yang berada didaerah Jakarta Barat tanpa harus perlu ke daerah Jakarta Utara karena dengan adanya Peraturan Pemerintah Nomor 24 Tahun 2016 tersebut PPAT yang berada didaerah Jakarta Barat maka dapat memproses jual beli tanah dan pendaftaran tanah serta hibah dan lain-lainnya.

Akibat yang ditimbulkan dari Peraturan Pemerintah Nomor 24 Tahun 2016 tersebut memang besar tetapi apabila saat ini terdapat klien yang mencoba ingin memproses jual beli tanah dan memaksa seorang notaris dan PPAT untuk menerapkan Pasal 12 Ayat satu Peraturan Pemerintah Nomor 24 Tahun 2016 tersebut maka PPAT dapat menolak hal tersebut karena memang belum bias diterapkan didalam prakteknya dan bagi PPAT yang melakukan penolakan 
terhadap hal tersebut tidak dapat dikenakan sanksi karena tidak ada penjelasan tentang pemberian sanksi terhadap PPAT yang melakukan penolakan terhadap klien tersebut.

c. Penyebab tidak efisiennya Peraturan Pemerintah Nomor 24 Tahun 2016

Penyebab tidak efisiennya pasal 12 Ayat satu Peraturan Pemerintah Nomor 24 Tahun 2016 tentang ruang lingkup wilayah kerja PPAT tersebut karena mungkin ada beberapa faktornya, menurut notaris Aris Hendrawan Halim yang berkantor di daerah Latumenten Jakarta Barat bahwa penyebab tidak efisiennya pasal 12 Ayat satu tersebut karena mungkin pemerintah terlalu terburu buru saat membuat isi yang berada di dalam pasal tersebut dan mungkin juga karena pada saat pembuatan peraturan tersebut tidak disertai para ahli dan PPAT maka dari itu mereka menjadi tidak menduga bahwa Pasal 12 ayat satu tersebut ternyata sangat sulit di terapkan karena sistem online dari kantor BPN nya belum bisa menerapkan wilayah kerja PPAT tersebut menjadi satu provinsi.

Hal tersebut juga bertentangan dengan teori nilai dasar hukum yang dikemukakan oleh Gustav Radbruch yang dimana didalam teori tersebut terdapat nilai kepastian dan kemanfaatan. Kepastian itu sendiri merupakan kepastian terlaksananya undang-undang atau peraturan dalam praktiknya dan didalam peraturan tersebut tidak boleh menimbulkan keraguan dan logis dalam artian ia menjadi suatu sistem norma dengan norma lain sehingga tidak berbenturan atau menimbulkan konflik norma serta menurut Hans Kelsen harus ada aspek "seharusnya" atau das sollen sehingga Peraturan yang dibuat tersebut harus benarbenar jelas dan apa bila memang sudah disahkan oleh pemerintah maka seharusnya peraturan tersebut bisa diterapkan didalam praktek seperti yang seharusnya karena hal tersebut termasuk kedalam kepastian hukum.

Tetapi dalam prakteknya saat ini memang nilai dasar kepastian hukum tersebut tidak melekat dengan Peraturan Pemerintah Nomor 24 Tahun 2016 tersebut khususnya pada pasal 12 Ayat satu tentang wilayah kerja PPAT tersebut. Nilai dasar Kemanfaatan hukum merupakan suatu nilai yang menentukan apakah 
hukum tersebut telah bekerja secara efektif atau tidak didalam masyarakat. Seperti yang telah di jelaskan diatas tadi bahwa memang Peraturan Pemerintah Nomor 24 Tahun 2016 khususnya pada pasal 12 Ayat satu tersebut tidak bekerja secara efektif didalam ruang lingkup masyarakat.

Begitu juga dengan para notaris dan PPAT, mereka juga merasakan manfaat yang signifikan dengan tidak efisiennya Peraturan Pemerintah Nomor 24 Tahun 2016 khususnya pada pasal 12 Ayat satu tentang wilayah kerja PPAT tersebut karena mereka seharusnya bisa memperbesar profit atau keuntungan mereka karena dengan adanya Peraturan Pemerintah Nomor 24 Tahun 2016 tersebut para notaris dan PPAT tersebut seharusnya bisa mendapatkan customer atau pelanggan yang berada didaerah dekat dengan tempat tinggal kantor notaris dan PPAT tersebut karena kebanyakan keluhan dari masyarakat umum bahwa masyarakat menjadi kerepotan dengan Peraturan Pemerintah Nomor 37 Tahun 1998 tersebut.

Penyebabnya terjadi karena keterbatasan dalam wilayah kerja nya yang hanya sebatas kabupaten saja. Tetapi dengan adanya Peraturan Pemerintah Nomor 24 tahun 2016 tersebut khususnya pada wilayah kerja PPAT yang diperluas menjadi satu provinsi tersebut maka masyarakat akan dipermudah untuk melakukan proses jual beli tanah dan lain-lainnya tanpa harus pergi ke daerah terdekat dengan tempat tanah yang ingin di proses tersebut karena jarak wilayah kerja nya tersebut telah diperluas menjadi satu provinsi sehingga yang berada di Jakarta Barat dapat di proses di daerah Jakarta Utara dengan adanya Peraturan Pemerintah Nomor 24 Tahun 2016 tersebut. Penyebab terjadinya tidak efisien Peraturan Pemerintah Nomor 24 Tahun 2016 tersebut menimbulkan beberapa dampak dan akibat yang akan dirasakan oleh masyarakat serta notaris dan PPAT.

\section{PENUTUP}

\section{A. Kesimpulan}

Berdasarkan hasil penelitian sebagaimana diuraikan pada bab-bab sebelumnya, penulis menyimpulkan bahwa Peraturan Pemerintah Nomor 24 Tahun 2016 pasal 12 
Ayat satu tentang wilayah kerja PPAT tersebut memang belum bisa diterapkan karena tidak ada efektivitas yang terjadi pada prakteknya karena terdapat beberapa faktor yang menyebabkan tidak efisiennya pasal 12 Ayat satu Peraturan Pemerintah Nomor 24 Tahun 2016 tersebut. Beberapa faktor yang menyebabkan tidak efisiennya Peraturan Pemerintah Nomor 24 Tahun 2016 tersebut karena sistem online untuk penginputan data yang ada di kantor notaris dan PPAT tersebut tidak bisa memproses jual beli tanah dan lain-lainnya yang wilayah kerja nya seluas provinsi serta peraturan yang masih digunakan saat ini yaitu Peraturan Pemerintah Nomor 37 Tahun 1998 yang telah dicabut oleh pemerintah yang isinya menerangkan bahwa ruang lingkup wilayah kerja PPAT tersebut seluas kabupaten atau kotamadya.

Sehingga akibat yang ditimbulkan dari tidak efisiennya Peraturan Pemerintah Nomor 24 Tahun 2016 tersebut yaitu berupa tidak adanya kepastian hukum serta kemanfaatan hukum. Penyebab terjadinya tidak efisiennya Peraturan Pemerintah Nomor 24 Tahun 2016 pada pasal 12 Ayat satu tersebut karena mungkin terjadi kesalahan dan kurang ketelitian pada saat pembuatan Peraturan Pemerintah Nomor 24 Tahun 2016 tersebut dan karena pada sistem online yang telah di buat BPN tersebut tidak bisa digunakan seperti yang seharusnya dalam artian sistem online yang digunakan BPN tersebut hanya bisa digunakan sebatas seluas kabupaten saja sedangkan seharusnya bisa digunakan untuk seluas satu provinsi. Tidak efisiennya Peraturan Pemerintah Nomor 24 Tahun 2016 tersebut juga bertentangan dengan asas hukum umum yaitu asas lex posterior derogate legi priori yang seharusnya asas tersebut dapat dijalankan seperti yang seharusnya tetapi justru asas tersebut kelihatan seperti dikesampingkan begitu saja.

\section{B. Saran}

Penulis memberikan beberapa saran yang sekiranya dapat dijadikan sebagai pertimbangan dalam hal terjadinya tidak efisiennya Pasal 12 Ayat satu Peraturan Pemerintah Nomor 24 Tahun 2016 tersebut yaitu pemerintah seharusnya saat membuat suatu peraturan baik itu berupa peraturan perundang-undangan, peraturan pemerintah, kebijakan dan lain-lainnya seharusnya lebih dapat diperhatikan lagi 
dengan teliti dan seksama sebelum peraturan tersebut telah di sahkan karena banyak sekali contoh-contoh lainnya selain Peraturan Pemerintah Nomor 24 Tahun 2016 yang pada saat peraturan tersebut telah di sahkan tetapi peraturan tersebut tidak efektif dalam prakteknya karena banyak faktor-faktor yang menghambat penerapan peraturan tersebut dalam lingkungan masyarakat. Tentu saja akibatnya akan menimbulkan beberapa dampak yang akan dirasakan oleh masyarakat dan notaris serta PPAT yang bersangkutan, oleh karenanya pemerintah harus lebih hati-hati dalam membuat suatu peraturan.

\section{DAFTAR PUSTAKA}

Adjie, Sjaifurrachman Habib. Aspek Pertanggungjawaban Notaris dalam Pembuatan Akta. Jakarta: Mandar Maju, 2011

Apeldroon, Van. Pengantar Ilmu Hukum. Jakarta: Pranya Paramita, 2001

AF, Hasanudin. Pengantar Ilmu Hukum. Jakarta: Pustaka Al Husna Baru, 2004

Machmudin, Dudu Duswara. Pengantar Ilmu Hukum. Bandung: Refika Aditama, 2010

Indonesia. Undang-undang Nomor 2 Tahun 2014 tentang Jabatan Notaris (LembaranNegara Republik Indonesia Tahun 2004 Nomor 117, Tambahan Lembaran Negara Republik Indonesia Nomor 4432, Tambahan Lembaran Negara Republik Indonesia Nomor 5491

Indonesia, Peraturan Pemerintah Nomor 24 Tahun 2016 tentang peraturan Pejabat Pembuat Akta Tanah (Lembaran Negara Republik Indonesia Tahun 1998

Nomor 52, Tambahan Lembaran Negara Republik Indonesia Nomor 3746, Tambahan Lembaran Negara Republik Indonesia Tahun 2016 Nomor 120 Asyhadie, Zaeni. Pengantar Ilmu Hukum. Jakarta: PT RajaGrafindo Persada, 2014 Marzuki, Peter Mahmud. Penelitian Hukum, Edisi Revisi. Jakarta: Kencana Prenada Media Group, 2011 